\title{
Coats-like exudative vitreoretinopathy (CLEVER) in CEP290 inherited retinal degeneration
}

\author{
Ann O'Connell, ${ }^{1,2}$ Kirk A J Stephenson (1) ${ }^{1,2}$ Julia Zhu, $^{2}$ Susan FitzSimon ${ }^{1}$
}

${ }^{1}$ Ophthalmology, Temple Street Children's University Hospital, Dublin, Ireland

${ }^{2}$ Ophthalmology, Mater Misericordiae University Hospital, Dublin, Ireland

\section{Correspondence to} Dr Kirk A J Stephenson; kirkstephenson@hotmail.com

Accepted 16 December 2021

\section{DESCRIPTION}

A 2-year-old female patient was diagnosed on clinical and electrophysiological grounds with an early onset rod-cone dystrophy (RCD). She had no systemic medical problems including cardiac, renal and neurodevelopmental systems. She was followed annually by her ophthalmologist and was noted at age 13 years to have developed left eye inferotemporal retinal exudation encroaching on the inferior macular arcades (figure 1A) with confirmation of telangiectatic vessels on fluorescein angiography (FFA, figure 1B). Her right eye showed features of RCD without exudative change (figure 1C). Although visual acuity (VA) was good at $6 / 18$ and 6/9 in right and left eyes, respectively, in order to preserve vision, she underwent cryotherapy and laser photocoagulation to telangiectatic vessels with interval reduction of subretinal exudation (figure 2). Whole exome sequencing confirmed compound heterozygous mutations (c.1781T>A,p.Leu594\%/c.2888A>G,p. Glu963Gly) in the CEP290 gene (12q21.32) without other inherited retinal degeneration (IRD)-associated variants detected. These variants were pathogenic and likely pathogenic, respectively, by the American College of Medical Genetics criteria. This confirmed a molecular diagnosis of non-syndromic 'Leber congenital amaurosis (LCA) 10' complicated by left Coatslike exudative vitreoretinopathy (CLEVER). Her younger brother (8 years) also had RCD/ LCA (without evidence of CLEVER) with the same compound heterozygous CEP290 variants detected.

RCD is the classic IRD phenotype with numerous genetic aetiologies. CLEVER reportedly complicates $1 \%-5 \%$ of RCD, developing at $18-35$ years, and is considered a vasoproliferative process secondary to the vascular/dystrophic changes of RCD. ${ }^{1-4}$ CLEVER has been reported in several IRD genotypes (eg, CEP290, CNGB1, CRB1, CRX, NMNAT1, PRPF8, RHO, RPGR, TULP1) and phenotypes (eg, non-syndromic RCD, LCA and Usher syndrome). ${ }^{145}$ A clear inheritance pattern for CLEVER is not apparent. ${ }^{6}$ Indeed, the CEP290 variants in this case differ from those previously reported, suggesting that CLEVER is not mutation-specific but rather a secondary reactive feature catalysed by retinal degeneration. The mechanism is thought to be focal vascular dilatation and compromise of the blood-retinal barrier in response to physiological stressors (eg, RCD, surgical trauma). ${ }^{3}$

CLEVER is most frequently binocular (78\%) in contrast to isolated Coats disease which is monocular in $75 \%$ of cases. ${ }^{17}$ It may be noted synchronously with RP diagnosis (33\%) or later in the disease course. ${ }^{1}$ The retinal telangiectasias and subretinal exudation are typically inferotemporal. ${ }^{1}$ CLEVER may be detected earlier (ie, presymptomatically) in patients undergoing clinical review for existing conditions (ie, RCD) than in isolated Coats disease, thus, CLEVER may have a more favourable prognosis due to earlier initiation of intervention. FFA may be beneficial in confirming diagnosis and guiding treatment which relies on laser photocoagulation or cryotherapy of leaking telangiectatic vessels with response rates similar to cases of isolated Coats disease. ${ }^{3}{ }^{8}$ Shields et al reported $39 \%$ with VA $\leq 6 / 18$ and $18 \%$ with VA $\leq 6 / 60$ (ie, legally blind); however, this review included cases prior to modern intravitreal therapeutic options. While topical carbonic anhydrase inhibitor therapy is effective for RCD-related cystic maculopathy $(\mathrm{CM}),{ }^{9}$ the $\mathrm{CM}$ associated with CLEVER, which develops in $<50 \%$, may be refractory to this method and require intravitreal therapy
Check for updates

(c) BMJ Publishing Group Limited 2022. No commercial re-use. See rights and permissions. Published by BMJ.

To cite: $O^{\prime}$ Connell $A$, Stephenson KAJ, Zhu J, et al. BMJ Case Rep 2022:15:e247229 doi:10.1136/bcr-2021247229

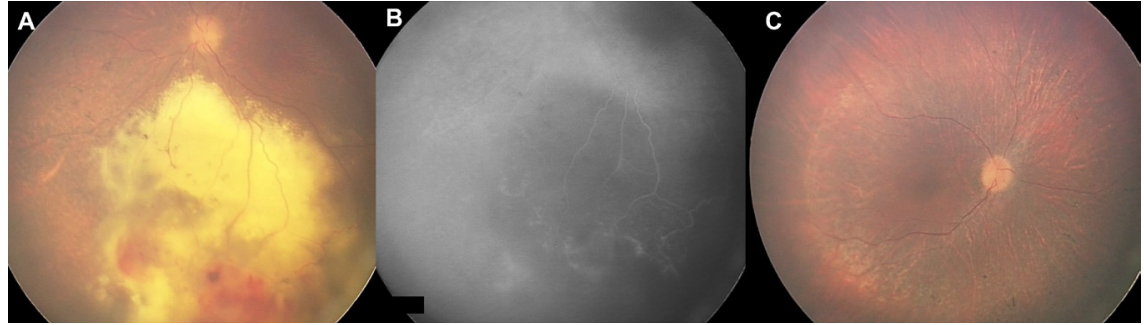

Figure 1 RetCam images (Clarity Medical Systems, USA). (A) Colour fundus photograph of the left eye showing rod-cone dystrophy (RCD) features (bone spicule-like pigmentation, arteriolar attenuation, waxy optic disc pallor) and extensive inferotemporal retinal/subretinal exudation. (B) Fluorescein angiography showing lightbulb telangiectatic vessels within the area of exudate. (C) Colour fundus photograph of the right eye showing RCD features without evidence of exudation. 


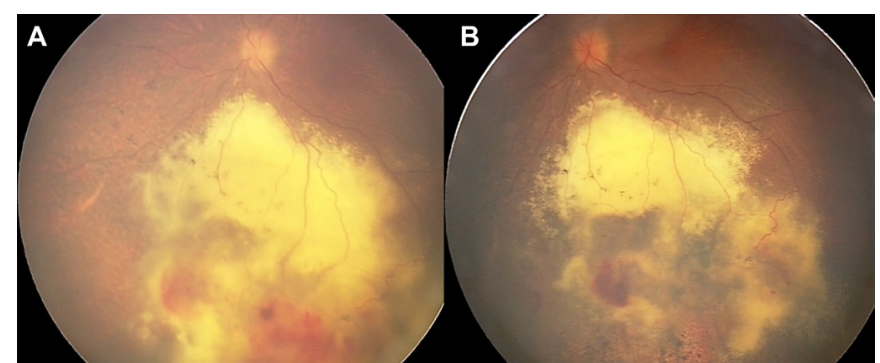

Figure 2 Colour fundus photographs of the affected inferotemporal fundus showing the interval regression of exudation from before $(A)$ and after (B) treatment with exudate retreating from the macular arcades. Note stigmata of cryotherapy and laser.

with anti-vascular endothelial growth factor or dexamethasone implant. ${ }^{110}$

\section{Learning points}

Coats-like exudative vitreoretinopathy may complicate up to $5 \%$ of cases of inherited retinal degenerations including rod-cone dystrophy, Leber congenital amaurosis and Usher syndrome.

- Treatment is as per isolated Coats disease (ie, laser photocoagulation and/or cryotherapy to telangiectatic vessels) with intravitreal antivascular endothelial growth factor or dexamethasone implant for macular involvement.

- Prognosis is good with visual acuity $>6 / 18$ in $61 \%$, though vision may deteriorate due to progression of the primary underlying inherited retinal degeneration.

\section{Twitter Ann O'Connell @oconnann and Kirk A J Stephenson @KarkStaphonsen}

Acknowledgements The Target 5000 Programme for Inherited Retinal Degenerations. Prof. David Keegan. Fighting Blindness Ireland.
Contributors $A O^{\prime} C$, KAJS and SF: patient care, manuscript drafting and revision. JZ: coordination of genetic testing and manuscript revision.

Funding The authors have not declared a specific grant for this research from any funding agency in the public, commercial or not-for-profit sectors.

Competing interests None declared.

Patient consent for publication Consent obtained from parent(s)/guardian(s)

Provenance and peer review Not commissioned; externally peer reviewed.

Case reports provide a valuable learning resource for the scientific community and can indicate areas of interest for future research. They should not be used in isolation to guide treatment choices or public health policy.

ORCID iD

Kirk A J Stephenson http://orcid.org/0000-0002-7462-7725

\section{REFERENCES}

1 Moinuddin O, Sathrasala S, Jayasundera KT, et al. Coats-like exudative vitreoretinopathy in retinitis pigmentosa: ocular manifestations and treatment outcomes. Ophthalmol Retina 2021;5:86-96.

2 Pruett RC. Retinitis pigmentosa: clinical observations and correlations. Trans Am Ophthalmol Soc 1983;81:693-735.

3 Shields CL, Kaliki S, Al-Dahmash S, et al. Retinal vasoproliferative tumors: comparative clinical features of primary vs secondary tumors in 334 cases. JAMA Ophthalmol 2013;131:328-34

4 Magliyah M, Alshamrani AA, Schatz P, et al. Clinical spectrum, genetic associations and management outcomes of Coats-like exudative retinal vasculopathy in autosomal recessive retinitis pigmentosa. Ophthalmic Genet 2021:42:178-85.

5 Han J, Kim TY, Kim M. Coats-like exudative vitreoretinopathy in NMNAT1 Leber congenital amaurosis. Ophthalmol Retina 2021:5:624.

6 Khan JA, Ide CH, Strickland MP. Coats'-type retinitis pigmentosa. Surv Ophthalmol 1988;32:317-32

7 Sigler EJ, Randolph JC, Calzada Jl, et al. Current management of coats disease. Surv Ophthalmol 2014;59:30-46.

8 Lodato G, Giuffre G, Anastasi M. [Peripheral retinal telangiectasis in retinitis pigmentosa]. J Fr Ophtalmol 1987;10:777-82.

9 Strong S, Liew G, Michaelides M. Retinitis pigmentosa-associated cystoid macular oedema: pathogenesis and avenues of intervention. Br J Ophthalmol 2017:101:31-7.

10 Patil L, Lotery AJ. Coat's-like exudation in rhodopsin retinitis pigmentosa: successful treatment with an intravitreal dexamethasone implant. Eye 2014;28:449-51.

Copyright 2022 BMJ Publishing Group. All rights reserved. For permission to reuse any of this content visit

https://www.bmj.com/company/products-services/rights-and-licensing/permissions/

BMJ Case Report Fellows may re-use this article for personal use and teaching without any further permission.

Become a Fellow of BMJ Case Reports today and you can:

- Submit as many cases as you like

- Enjoy fast sympathetic peer review and rapid publication of accepted articles

- Access all the published articles

Re-use any of the published material for personal use and teaching without further permission

Customer Service

If you have any further queries about your subscription, please contact our customer services team on +44 (0) 2071111105 or via email at support@bmj.com.

Visit casereports.bmj.com for more articles like this and to become a Fellow 